\title{
"Hacks" and "Long Hairs": The Question of a DNC Research Division, 1948-1952
}

\author{
Sean Savage, St. Mary's College
}

Since the American Political Science Association's 1950 report on the American two-party system, political scientists have concentrated on the conditions. behavior, functions, and objectives of national party organizations. Besides examining organizational and functional changes, political scientists have also explored the different styles of and motives for participation in party organizations by different types of party activists, especially the differences between reformers and regulars. This study explains a prolonged conflict over the creation of a permanent research division for the Democratic National Committee headquarters during the Truman administration. It analyzes the different perspectives and roles of "hacks," i.e., party regulars, and "long hairs," i.e., the researchers and their White House allies, during this struggle. The framework of this case study and the different political actors examined may be used to analyze similar conflicts over organizational changes in party structures during other presidencies. This article concludes that the current research and publicity activities of the DNC under chairman David Wilhelm will seek to alleviate differences between party regulars and issue activists as it tries to identify the Clinton administration's more centrist domestic policy goals with the Democratic party.

\section{The Study of Party Organizations Since 1950}

After the American Political Science Association's Committee on Political Parties issued its report, "Toward a More Responsible Two-Party System," in 1950, political scientists increasingly explored factors which change the structure, functions, objectives, and behavior of party organizations and those who participate in them. Political scientists have differed over whether this report's conclusions and recommendations for a stronger, more centralized, disciplined, and policy-oriented two-party system are feasible or even desirable (David 1992; Ranney 1951; Ranney 1954; Turner 1951; Pomper 1971; Goldman 1992). President Harry Truman, however, agreed with much of the report. His White House aides urged him to direct the Democratic National Committee (DNC) chairman to establish a permanent research division for the DNC headquarters, as recommended by the report (American Political Science Association 1950, 31; Gross 1992; Goldman 1992).

SEAn J. SAvage is Assistant Professor of Political Science at St. Mary's College in Notre Dame. IN.

The American Review of Politics, Vol. 15. Spring. 1994: 57-72

${ }^{\circ} 1994$ The American Review of Politics 
Major studies of the two national party organizations during the 1950s and 1960s stressed their ostensibly weak, decentralized structure and the inability of their chairmen, members, and staff to exert much influence on their parties' ideological and programmatic direction and identity with voters (Cotter and Hennessy 1964; Bone 1958). By the early 1970s, some studies even concluded that national party organizations would wield even less influence over their parties' nominees, campaign strategy, and policy positions as candidates adapted to the growing dealignment and independence of voters (Broder 1971; Burnham 1975).

The Democratic and then the Republican parties implemented reforms that changed the relationships between their national and state committees and the rules for the selection of delegates during the 1970s (Sorauf and Beck 1988; Shafer 1983; Crotty 1983). Political scientists now concentrated on the importance of the national committees and their reform commissions as structures which nationalized the rules and democratized the process of presidential nominations. They also studied how these organizational and procedural changes sometimes led to unexpected or unfavorable consequences (Polsby 1983; Longley 1977; Longley 1980; Longley 1981; Ceaser 1983).

During the 1980s, successful efforts of Republican national chairman William Brock (1977-1981) to significantly expand and improve the campaign service functions of the Republican National Committee (RNC) to Republican nominees and state committees led to reactive efforts by the DNC headquarters to match this ability. More political scientists now began to conclude that the national party organizations were experiencing renewal and developing more cooperative, productive relationships with state committees and party nominees as they focused more on campaign services and fund raising (Wekkin 1984; Sabato 1988; Kayden 1985; Klinkner 1993).

\section{Two Opposing Camps of Party Activists}

Beyond the questions of whether national party organizations were rising or declining in power and purpose in national party politics and of how and why they were changing their functions, methods, and objectives during these different periods, political scientists have also examined how different political actors in national party organizations and presidential campaigns perceive and behave in different and often conflicting ways. In particular, scholars often distinguish these two types of actors according to whether their behavior in party organizations and campaigns primarily avocational and oriented toward ideological, programmatic, or candidatecentered motives or is professional and emphasizes a more pragmatic 
approach for the sake of intra-party harmony, patronage, voter appeal, or electoral success (Burns et al. 1992; Sullivan et al. 1974; Kirkpatrick 1976; David 1960; Ranney 1975; Pomper 1980; Maisel 1987; Herrera and Taylor 1993). James Q. Wilson (1962) noted the different motives and objectives of the 1950s-era anti-machine, reformist "amateur" Democrats and the party professionals who often opposed them.

Likewise, Nelson Polsby and Aaron Wildavsky (1976) noted a similar distinction between "purists" primarily motivated by ideology, issues, or the personal appeal of candidates and party professionals who are often more cautious and moderate in their attitudes and approaches to such intra-party matters as nominating conventions, policy positions, and campaign tactics. After Charles Longley analyzed the differences between "reformers" and "regulars" on the DNC's Compliance Review Commission (CRC), he concluded "that party reform promotes numerous tensions, not the least of which are organization relationships" (1977, 20). More recently, Jon F. Hale (1992) distinguished ideological, behavioral, and policy differences between New Politics liberals and centrists, such as Bill Clinton, of the Democratic Leadership Council (DLC) in recent presidential campaigns.

Comparatively, these intra-party conflicts of party regulars and more ideological within the two major American parties have tended to be more intractable than those within continental West European countries (Epstein 1980; Hartz 1955; Duverger 1951). Unlike their American counterparts, European party regulars have often perceived a greater need to appease and coopt the philosophical and platform demands of the more extreme party activists and intellectuals for the sake of party unity and electoral victory within the more divisive, ideological politics of European multi-party systems (Hine, 1986; Lipset and Basu 1976; Panebianco 1988). By contrast, American party regulars often fear that greater policy, organizational, and campaign influence by ideological activists will weaken the party's appeal to the centrist majority of American voters (Key 1947, 225-235; Klinkner 1993, 135; Klinkner 1992, 21-26; Ranney 1975).

More specifically, regulars and ideologues have often differed over the party function of issue and policy research. Regulars have frequently regarded research to be a lower priority among party functions and wanted to avoid researching and developing policy positions that aggravate intra-party differences, as civil rights proposals did the Democratic party during the Truman administration (Price 1984, 289; Klinkner 1992, 44-45; Hale 1993; Martin 1979). Regulars often have perceived the substance and purpose of research to be publicity attacks and reactions to the opposing party's policies and publicity activities, especially by focusing on consensus-building economic issues (Michelson 1944; Redding 1958; Morin 1991). In contrast, 
more issue-oriented, ideological activists often have perceived research by national party organizations to be a high priority and have believed that the parties should clarify and distinguish their ideologies and policy agendas through well-researched, assertive positions. These activists are more likely to believe that expressing such differences is important enough for defining the party's identity and achieving major policy goals to risk party disunity, and even electoral defeat (Rauh 1991; Klinkner 1992, 65-72; Gillon 1987; Wilson 1962, 369-370).

\section{Hacks and Long Hairs of the Truman Era}

None of the above analyses of these two types of participants in party organizations, however, examined the similar division that emerged within Harry S. Truman's campaign in 1948 and persisted more severely until the end of 1952 Democratic campaign (Batt 1991; Dreyer 1991; Gross 1992; Goldman 1992). During this period, a prolonged struggle occurred between "hacks," i.e., three successive DNC chairmen and their top headquarters staff, and "long hairs, " i.e., more liberal, policy-oriented White House aides and campaign researchers, over whether the DNC should create and maintain a permanent, active research division. "Hacks" and "long hairs" were the disparaging terms that each camp used to refer to the other (Hechler 1991; Dreyer 1991; Barriere 1991). Similar to the distinctions noted by Wilson, Polsby, Wildavsky, and Hale, the "hacks" of the DNC headquarters stressed intra-party harmony, a moderate, cautious approach to such divisive issues as Truman's civil rights proposal, fund raising, and patronage distribution. Like the more ideological activists previously noted, the "long hairs" tended to be younger, well-educated, and emphasize the aggressive advocacy and pursuit of controversial liberal policy objectives such as civil rights and national health insurance In Truman's campaign rhetoric and presidential behavior from 1948 to 1952 (Neustadt 1991; Batt 1991; Gross 1992).

While this analysis uses a similar distinction and framework as the above theories, this study examines several factors which these other works have not clearly and fully addressed. First, this case study concerns a conflict over a structural and functional change within a national party organization while that party controls the presidency and a change occurs in the party control of Congress. Second, it explores the role of the White House staff as persistent advocates of an organizational change opposed by the national party chairman. Third, this article illustrates the limitations of the ability of the president as party leader to make a minor structural and functional change in his party's national headquarters if this change is opposed by his party's national chairman. 
This study concentrates on an extended conflict regarding a proposed organizational change in the DNC headquarters during the Truman administration. The structure of the analysis, however, can be used to examine other conflicts over party organization involving a president, one or more successive national party chairmen, White House staff, and administration officials, and the extent to which national party chairmen and administration officials can influence a president's perceptions and decisions regarding his party's national organization. This framework especially can be used to discern the degree to which White House aides and other administration officials can act as "political entrepreneurs" in solving a political problem and advancing their policy interests through an organizational change in their party (Herrnson and Menefee-Libey 1990).

\section{The Success of the 1948 DNC Research Division}

The idea to create a research unit for Harry S. Truman's 1948 campaign was formulated and introduced to the president by White House aides and cabinet members, not DNC officials. They wanted a research division that technically would be part of DNC headquarters by having the researchers' salaries and office expenses paid by the DNC treasury. But this unit would be under the direct, exclusive authority of the administration officials managing Truman's campaign, especially Clark M. Clifford, special counsel to the president. Senator J. Howard McGrath, DNC chairman from 1947 to 1949, complied with Truman's request for such a research division but disliked its independence from his authority and its consumption of scarce campaign funds (Hoeber 1966; Birkhead 1966).

Truman's campaign staff realized that a full-time group of researchers would be necessary to provide the facts on all of the policy issues that he would address as well as the facts on local politics, economics, history, demography, and recent events in each community that Truman would visit. Besides the fact that the DNC headquarters lacked the resources and staff to perform this task, Clifford and other liberally-inclined administration officials assumed that party regulars in general lacked the creativity, initiative, and intellectual orientation toward issues, policies, and ideas that were necessary in order to successfully conduct and transmit such vital research for Truman's whistle stop campaign (Clifford 1947, 40). Undersecretary of labor David Morse, a member of Clifford's strategy group, recommended William L. Batt, Jr. as director of the newly-created DNC Research Division. Clifford contacted Batt, and DNC chairman McGrath formally appointed Batt on 8 March 1948 (Redding 1948). 
Batt requested and received a nine-month budget of $\$ 80,000$ and the discretion to choose and hire six researchers and two secretaries. McGrath claimed that the Ring Building lacked office space for Batt's organization, so the Research Division was housed in a hot, cramped office next to a noisy construction site near Dupont Circle (Batt 1966, 3-4). Most of the researchers dismissed McGrath's claim as an excuse to prevent the presence of the "long hair" researchers at DNC headquarters (Birkhead 1966, 34-35; Barriere 1991). The geographic distance in Washington between the DNC headquarters and the Research Division office would exacerbate the organizational and ideological gap that already existed between them.

Batt and the members of his research staff were oriented toward ideological and policy issues and not toward the matters of patronage, fund raising, and intra-party harmony that concerned party regulars and DNC headquarters. All of the researchers were members of the Americans for Democratic Action (ADA) and/or the American Veterans Committee (AVC) (Batt 1991). Most of them were in their late 20s or early 30s in age, World War II veterans, well-educated, and committed to an internationalist, UNoriented foreign policy, civil rights for blacks, and expanded social welfare programs. Except for Kenneth Birkhead, who had been active in the Pendergast machine of Kansas City, the researchers had not been experienced regulars in Democratic party organizations. Furthermore, Batt and Johannes Hoeber had participated in anti-machine reform movements in Philadelphia. Concerned about the loyalty and future voter mobilization efforts of Democratic machine bosses, both the White House staff and DNC headquarters wanted to ensure that the Research Division was unknown to party regulars and the press (Hoeber 1966, 27-28).

When the DNC Research Division formally was dissolved on 1 October 1948 , it had prepared about 300 rough drafts for these whistle stop speeches in addition to the many facts and statistics on public policy that the researchers obtained from federal agencies (Birkhead 1966, 11). More importantly, though, the Research Division recommended to Truman probably the two most effective rhetorical tactics of Truman's campaign strategy. They were his call for a special session of Congress and his persistent attack on the Republican-controlled Congress's failure to allocate funds for new grain storage facilities to accommodate the bumper wheat and corn crops of 1948. The DNC researchers believed that this rhetorical approach by Truman reminded voters of the ideological and policy differences between the two parties and contributed to Truman's upset victory and the return to a Democratic Congress (Batt 1966, 39-40). 


\section{The Conflict Over a Permanent DNC Research Division}

Following the election, Truman's White House staff, especially Clark Clifford, George Elsey, and Charles Murphy, recognized the crucial need for a permanent DNC Research Division in order to inform the White House of the roll call votes of Republicans in Congress, help the DNC and the White House to explain and promote the Fair Deal, respond to Republican and press criticism of the Truman administration, and help Truman prepare campaign speeches (Hechler 1991; Dreyer 1991). If a full-time, permanent DNC Research Division would be so beneficial to Truman and the national Democratic party's policy goals and electoral interests, would the DNC chairman agree to implement and finance such an operation?

During J. Howard McGrath's final months as chairman, DNC headquarters appeared to be willing to accept a permanent Research Division as long as it was clearly subordinate to the chairman and publicity director (Redding 1948). However, on 8 February 1949 William M. Boyle, Jr. was appointed vice chairman of the DNC to assume many of McGrath's duties, and subsequently was elected chairman on 24 August 1949. Boyle squelched White House efforts to create a permanent Research Division during his two-year tenure.

Boyle's background in the Democratic party typified that of the "hack" or party regular. His entry into politics began at the age of 16 when he established a Young Democrats Club in his ward in Kansas City (McCullough 1992, 867-879). Boyle disliked the prospect of liberal, intellectual "long hairs" assuming a prominent, influential presence at DNC headquarters (Hechler 1991; Dreyer 1991). Like most party hacks, Boyle perceived intra-party harmony, fund raising, and patronage distribution to be the primary functions of DNC headquarters. He regarded the liberal long hairs' emphasis upon ideological and policy matters-especially civil rights legislation-as detrimental to intra-party relations and beyond the proper jurisdiction of DNC headquarters (Hechler 1982, 10-11; Hechler 1991).

\section{The White House Staff and a DNC Research Division}

Ken Hechler, a former college professor and White House researcher, most clearly and persistently represented the view of the White House staff that the DNC headquarters should create and maintain a permanent Research Division devoted entirely to partisan research. Busy with research and writing on policy matters for Truman, Hechler agreed to conduct the local research and prepare the speech outlines for Truman's 1950 and 1952 whistle stop campaigns (Hechler 1982, 132-145, 249-252). Hechler believes 
that the 1950 Democratic congressional losses would have been fewer and, shortly thereafter, Republican charges of corruption in the Truman administration and of an incompetent military strategy in the Korean War would have been less damaging if a full-time DNC Research Division had been actively and regularly responding with fact-filled publicity (Hechler 1991).

In an 11 July 1950 memo to Truman, Murphy and Elsey urged the president "to talk with Bill Boyle, emphasizing the importance of additional staff for the research work of the Committee" (Murphy 1950). Phil Dreyer, a member of the 1948 research unit who wrote much of Truman's material on the Korean War for his 1950 speaking trip, surmises that Boyle would appease Truman by agreeing with this recommendation but would then fail to implement it. Boyle knew that Truman's staunch loyalty would prevent the president from dismissing him over this (Dreyer 1991).

\section{Growing Opposition to Boyle}

With Democrats in Congress and on the White House staff urging Boyle's removal and Truman reluctant to fire his Pendergast crony, Boyle resigned on 13 October 1951, citing ill health. In his letter of resignation amidst allegations of influence peddling and vocal complaints about his lethargic leadership as chairman, Boyle assured Truman "that affairs of the Democratic National Committee are in excellent condition. The party organization throughout the country is strong and imbued with confidence in the rightness of our program" (New York Times 14 October 1951). Few Democrats in Congress and on the White House staff shared Boyle's optimism about the condition of the DNC headquarters and its ability to prepare their party for the 1952 campaign. In particular, they wanted a chairman who would establish a well-funded, thoroughly-staffed DNC Research Division which could conduct the research and provide the facts necessary for Truman and Democratic congressional nominees to refute Republican charges of corruption and convince the public to vote Democratic in 1952 (Dunar 1984, 109-112, 127-135).

\section{McKinney as DNC Chairman: 1951-1952}

The White House staff initially was pleased with the appointment and subsequent election of Frank E. McKinney as Boyle's replacement (Hechler 1991). McKinney, an Indianapolis banker and political ally of Indiana DNC member Paul M. Butler, had distinguished himself as a party fund raiser but, unlike Boyle, was not a seasoned party regular and appeared more receptive the organizational reform of DNC headquarters. In his 31 October 
1951 acceptance speech, McKinney promised to streamline DNC staff, ensure that its DNC employees did not peddle influence with federal agencies to lobbyists, and "to re-establish the political research, publicity and informational activities of the Committee which once reached such a high level of effectiveness ..." (McKinney 1951a). On the following day, McKinney announced a decrease in the patronage function of the DNC by formally adopting Truman's proposal to end DNC appointment of Bureau of Internal Revenue collectors (McKinney 1951b).

By January of 1952, McKinney was adopting plans for a new DNC Research Division submitted by Bertram Gross, the executive director of the Council of Economic Advisers. The White House staff had suggested to Truman and McKinney that Gross be appointed as head of the new DNC Research Division (Hechler 1991; Gross 1992). Unlike the 1948 DNC Research Division, Gross's operation enjoyed the full support of the DNC chairman, a larger budget, and closer coordination with Democratic congressional campaigns (Hechler 1991). Besides reprising for Adlai Stevenson the tasks that the 1948 division had performed for Truman's whistle stop campaign, the DNC Research Division also compiled and distributed campaign materials stressing economic progress and reform under Roosevelt and Truman and criticizing sources of Republican campaign funds (Gross 1952; Lewis 1952; DNC 1952).

But the most vigorous efforts of the research division and other units of the DNC headquarters could not prevent the seemingly inevitable and decisive election of Dwight Eisenhower and a Republican sweep of Congress (Neustadt 1991; Brightman 1991). Following the election, Steve Mitchell, the new DNC chairman, reduced the DNC headquarters' expenses and staff by merging research functions entirely into the Publicity Division (DNC Fact Sheet 1953; Bone 1958, 42-44).

\section{Democratic Research Activities of the DAC and DLC}

Much as Bill Batt and his research staff had sought to use policy research and suggested speeches for Truman's 1948 campaign to give the Democratic party a more clearly liberal identity and purpose on controversial issues such as civil rights and national health insurance, leading liberal Democrats such as Senator Hubert Humphrey and DNC chairman Paul Butler established the Democratic Advisory Council (DAC) shortly after the 1956 presidential election (Parmet 1976, 151-167; Klinkner 1992, 21-35). Opposed by Speaker Sam Rayburn and Senate majority leader Lyndon Johnson, the liberal DAC members disliked the Hill leadership's consensual, cooperative relationship with Dwight Eisenhower, and issued 
liberal policy statements on domestic policy issues such as right-to-work laws and school desegregation, often illuminating ideological and regional conflicts within the Democratic party in Congress and among the state parties (Butler 1956; Roberts 1987, 89-100). The DAC's policy committee included social scientists such as John Kenneth Galbraith and James Sundquist, who used their expertise and social skills to formulate liberal policy proposals ranging from new foreign aid programs to a greater federal role in public education (Klinkner 1992, 39-83). These DAC policy proposals greatly influenced the development and content of the Democratic national platform in 1960 (Bernstein 1991, 26-30).

While Democratic party research activities in the development of policy ideas often were more likely to be advocated and pursued by liberals, the Democratic Leadership Council (DLC) engaged in policy research and development for the purpose of creating and projecting a more centrist, instead of a more liberal, identity for the national Democratic party during the 1980s (Hale 1993). Bill Clinton, Al Gore, and other DLC members realized that they must promulgate well-researched, articulate, new policy ideas in order to distinguish this "New Democrat" identity. Jon F. Hale persuasively claims "that party identity is driven by ideas and issues and, therefore, moderates must fight ideas with ideas of their own, not vague statements about moving to the middle if they wish to reconstruct party identity" (Hale 1993, 19).

\section{DNC and RNC Research Activities: A Comparison}

As Phil Klinkner convincingly contends, the two major parties' national organizations tend to differ according to their organizational cultures. The Democratic party emphasizes the values of democracy, representation, and inclusion while the Republican party stresses business methods, centralization, hierarchy, and loyalty (Klinkner 1992, 317-351; see also Freeman 1986). Except for the factionalism that occurred due to Barry Goldwater's presidential candidacy, the Republican party generally has enjoyed greater internal ideological consensus than the Democratic party. In addition to more funds, this greater intra-party homogeneity and harmony has enabled the RNC chairmen and staff to concentrate more than their Democratic counterparts on conducting policy research as part of a campaign service and party-building strategy. Thus, the RNC recognized the utility of the constant formulation of policy ideas for attracting voters, recruiting and serving Republican candidates, and preparing for and waging successful presidential, congressional, and state campaigns (Sabato 1988, 77-81). This perception and concomitant emphasis was especially evident at RNC headquarters 
during the chairmanships of Ray Bliss (1965-1969) and Bill Brock (19771981 ) and helped Bliss and Brock to obscure ideological differences between the conservative and moderate-to-liberal wings of their party (Klinkner 1993; Rae 1989, 83-87).

In contrast, Democratic party research for the formulation and advocacy of policy ideas had often accentuated rather than obscured intraparty ideological differences. Furthermore, the DNC's organizational culture, inadequate funding, and its concentration on rules reform and its consequences hampered its ability to equal the RNC's campaign-oriented research and other campaign service activities during the 1970s and early 1980s (Sabato 1988, 76-81; Broder 1991).

\section{A Permanent DNC Research Division}

While "out party" DNC chairman Paul Butler had sought to preserve and enhance the Democratic party's liberal identity in its ideology, policy agenda, and voter appeal and risked the opposition of Democratic congressional leaders and intra-party discord through policy research and other DAC and DNC activities, "out party" DNC chairman Ron Brown (19891993) more closely followed the role model for an "out party" chairman established by Bliss and Brock. Like Bliss and Brock, Brown obscured internal policy and ideological factionalism by making the coordinated campaign strategy the centerpiece of his tenure. One aspect of this strategy was the operation of a well-funded, permanent, full-time DNC Research Division (Morin 1991). Brown wanted an expanded, permanent research operation to help the DNC headquarters provide more campaign services, information about Bush administration policies, greater coordination and agreement on issue positions for Democratic nominees at all levels of politics, and long-term preparation for the 1992 presidential campaign (Brown 1989; Travis 1991). The new DNC Research Division also helped Brown to assume a bolder, more prominent, and more pro-active role as his party's spokesman compared to his two "out party" predecessors (Carol 1991).

The more active, permanent DNC Research Division developed under Brown was primarily a product of three factors. First, Charles Manatt and Paul Kirk, Brown's immediate predecessors, had improved substantially the DNC headquarters's fund-raising ability, direct mail and media operations, and campaign service delivery to state parties (Sorauf and Beck 1988, 142153). Their accomplishments provided Brown with the financial ability and organizational precedents to adopt such a research operation. Second, three successive presidential election defeats and a decline in the proportion of 
registered Democrats during the 1980s had oriented the DNC headquarters' efforts more on electoral victory and, thus, a greater emphasis on policy and issue research for campaign and publicity purposes, and less on procedural matters and the representation of more ideological interest groups (Longley 1992, 41-48; Travis 1991; Morin 1991). Third, the DNC was responding to the well-funded, effective RNC Research Division that often had operated 24 hours a day in three 8-hour shifts during the 1988 presidential campaign, while the DNC's 1988 research division had operated usually for only eight hours a day, and did not get underway until July (Morin 1991). During the 1992 campaign, Brown had achieved his objective of developing an experienced, effective full-time DNC Research Division which closely coordinated its activities with those of Bill Clinton's campaign staff (Brown 1989; Morin 1991; Germond and Witcover 1993, 75-76, 86, 502-503).

\section{Conclusion}

From 1953 until 1989, there was no serious, successful effort by a Democratic president or DNC chairman to create and operate a full-time, multi-member DNC Research Division, except during presidential election years. Rather, they failed to establish such a unit, usually because of insufficient funds or a focus on other objectives for the DNC, such as the nomination rules reforms of the 1970s and the emphasis on improving fund raising and direct mail operations during the 1980s.

Shortly after the 1992 presidential election, David Wilhelm, a Clinton campaign manager and current DNC chairman, contacted former Reagan campaign aides Lyn Nofziger and Ed Rollins. Wilhelm wanted to know how the Reagan staff had been able to solicit so quickly the tens of thousands of letters and phone calls to Congress supporting Ronald Reagan's first-term policy proposals (U.S. News and World Report 1992, 38). In particular, the Clinton administration has given Wilhelm and the DNC staff a leading role in explaining and promoting its health care reform proposal. Wilhelm chose former Ohio governor Richard Celeste to organize DNC publicity efforts on behalf of health care, and the DNC Research Division provides facts about the plan to respond to questions and critics (Lees 1993). Wilhelm has concentrated his efforts on criticizing interest groups that oppose major White House legislation such as health care, while seeking to improve policy cooperation between congressional Democrats and the president (Berke 1993).

Thus, an "in" party's national chairman and headquarters need not lapse into inertia and obscurity if a president designates and encourages important political functions and objectives for them (Cotter and Hennessy 
1964, 81-94; Sabato 1988, 59-61; Cronin 1980). After noting the continuation of a vibrant RNC headquarters during the Reagan presidency, Sorauf and Beck concluded that "as the national parties continue their partybuilding, it will be in the service of presidential goals" (Sorauf and Beck $1988,151)$. In addition to their subordination to and service of Clinton's health care plan and other major policy objectives, the current DNC chairman and staff will also orient themselves toward reshaping the Democratic party's voter appeal and ideological-policy identity according to the more centrist "New Democrat" model adopted and projected by Clinton during his DLC membership and the 1992 campaign (Wattenberg 1993, 5-6; Germond and Witcover 1993, 100-101).

Under Clinton's presidency and Wilhelm's chairmanship, therefore, the current DNC headquarters may advance something akin to the more coherent, disciplined, policy-oriented two-party system that the APSA's 1950 report, Truman and the liberals in his administration, and DNC researchers in the 1948 and 1952 campaigns all had sought. Inevitably, conflicts over the purposes and methods of party organizations between "hacks" and "long hairs," "purists" and "professionals," and "regulars" and "reformers" will continue (Crotty 1983, 233-235). As Klinkner's organizational culture thesis claims and for the other reasons previously stated, these conflicts will be more evident and frequent within the Democratic party than the Republican party. When such occurrences afflict an "in" party's national organization, this case study and framework of the prolonged struggle over a proposed organizational change in the DNC headquarters during the Truman presidency will serve as a useful model for analyzing similar intra-party organizational change during other presidencies.

\section{APPENDIX}

In addition to the secondary works indicated in the text and bibliography. information also was obtained from personal and phone interviews of current and former DNC officials and Truman aides. Primary sources from several archival libraries also were used. The following are abbreviations used in the bibliography to signify the libraries that were researched for these sources: HLND-Hesburgh Library of the University of Notre Dame; HSTL-Harry S. Truman Library. Independence. Missouri; JFKL_John F. Kennedy Library, Boston. Massachusetts.

\section{BIBLIOGRAPHY}

American Political Science Association. 1950. Toward a More Responsible Two-Party System. New York: Rinehart and Company.

Barriere, John E. 1991. Phone interview. 13 October.

Batt, William L., Jr. 1966. Oral history interview. 26 July. HSTL.

1991. Interview in Middletown. CT. 20 July. 
Berke, Richard L. 1993. At a Gathering. Democrats Hear A Bugle Call to Meet Their Foes. New York Times 10 October.

Birkhead, Kenneth M. 1966. Oral history interview. 7 July. HSTL.

Bone, Hugh A. 1958. Party Committees and National Politics. Seattle: University of Washington Press.

Brightman, Samuel. 1991. Interview in Bethesda, MD. 12 July.

Broder. David. 1972. The Party's Over. New York: Harper and Row. 1991. Democrats Could Learn from GOP Policy Forums. South Bend Tribune. 18 September.

Brown, Ronald H. 1989. The Democratic Coordinated Campaign. Washington. DC: Democratic National Committee.

Burnham, Walter Dean. 1975. American Politics in the 1970 's: Beyond Party. In William Nisbet Chambers and Walter Dean Burnham, eds., The American Party Systems: Stages of Development. New York: Oxford University Press.

Burns, James MacGregor, William Crotty, Lois Lovelace Duke, and Lawrence D. Longley, eds. 1992. The Democrats Must Lead: The Case for a Progressive Democratic Party. Boulder. CO: Westview Press.

Butler, Paul. 1956. Letter to Turner Catledge. In Paul Butler Papers. HLND.

Carol. Daniel. 1991. Phone interview. 25 October.

Ceaser, James W. 1983. Reforming the Reforms: A Critical Analysis of the Presidential Selection Process. Cambridge, MA: Ballinger.

Clifford, Clark M. 1947. Memo from Clifford to Truman. 19 November. In Clark M. Clifford Papers. HSTL.

Cotter, Cornelius P. and Bernard C. Hennessy. 1964. Politics Without Power: The National Party Committees. New York: Atherton Press.

Crotty. William. 1983. Party Reform. New York: Longman.

David, Paul T. 1992. The APSA Committee on Political Parties: Some Reconsideration of Its Work and Significance. Perspectives on Political Science 21: 70-79.

, Ralph M. Goldman, and Richard C. Bain. 1960. The Politics of Party Conventions. Washington. DC: Brookings.

Democratic National Committee. 1952. How to Win in 1952. In Paul Butler Papers. HLND.

Dreyer, Philip. 1991. Phone interview. 24 October.

Dunar, Andrew J. 1984. The Truman Scandals and the Politics of Morality. Columbia: University of Missouri Press.

Duverger, Maurice. 1951. Political Parties: Their Organization and Activity in the Modern State. New York: John Wiley.

Epstein. Leon D. 1980. Political Parties in Western Democracies. New York: Transaction.

Freeman, Jo. 1986. The Political Culture of Democrats and Republicans. Political Science Quarterly $101: 327-356$.

Germond, Jack and Jules Witcover. 1993. Mad as Hell: Revolt at the Ballot Box. New York: Warner.

Goldman. Ralph M. 1990. The National Party Chairmen and Committees: Factionalism at the Top. New York: M.E. Sharpe. 1992. Phone interview. 18 September.

Gross, Bertram. 1992. Phone interview. 17 and 21 September.

Hale. Jon F. 1992. New Politics and Liberals and DLC Centrists: Factionalism in the Democratic Party, 1968-1992. Paper presented at the annual meeting of the American Political Science Association, Chicago, IL.

1993. A Different Kind of Democrat: Bill Clinton, the DLC, and the Construction of a New Party Identity. Paper presented at the annual meeting of the American Political Science Association, Washington. DC.

Hartz. Louis. 1955. The Liberal Tradition in America. New York: Harcourt. 
Hechler, Ken. 1982. Working With Truman. New York: G.P. Putnam's Sons. 1991. Phone interview. 27 August.

Herrera, Richard and Melanie Taylor. 1993. The Structure of Opinion in American Political Parties. Paper presented at the annual meeting of the Southwestern Political Science Association, New Orleans.

Herrnson. Paul and David Menefee-Libey. 1990. The Dynamics of Party Organizational Development. Midsouth Political Science Journal 11: 3-30.

Hine, David. 1986. Leaders and Followers: Democracy and Manageability in the Social Democratic Parties in Western Europe. In William Peterson and Alastair Thomas, eds., The Future of Social Democracy. New York: Clarendon Press.

Hoeber. Johannes. 1966. Oral history interview. 13 September. HSTL.

Kayden. Xandra and Eddie Mahe. Jr. 1985. The Party Goes On. New York: Basic Books.

Key, V.O., Jr. 1947. Politics, Parties, and Pressure Groups. New York: Thomas Y. Crowell Co. Kirkpatrick, Jeane. 1976. The New Presidential Elite: Men and Women in National Politics. New York: Russell Sage.

Klinkner, Philip A. 1993. A Comparison of Out-Party Leaders: Ray Bliss and Bill Brock. In John Green, ed., Politics, Professionalism, and Power: Modern Party Organization and the Legacy of Ray C. Bliss. New York: University Press of America.

1992. The Response of Political Parties To Presidential Defeats: A Study in Organizational Culture. Ph.D. dissertation, Yale University.

Lees, Kelly. 1993. Phone interview. 4 October.

Lewis, Anthony. 1952. Local Background Information for Stevenson Campaign. In Philip Stern Papers. JFKL.

Lipset, Seymour and A. Basu. 1976. The Roles of the Intellectual and Political Roles. In A. Gella. ed., The Intelligentsia and Intellectuals: Theory, Method, and Case Study. Beverly Hills, CA: Sage.

Longley, Charles H. 1977. Party Reform and Party Organization: The Compliance Review Commission of the Democratic Party. Paper presented at the annual meeting of the Northeastern Political Science Association, Mount Pocono, PA. 1980. National Party Renewal. In Gerald M. Pomper, ed., Party Renewal in America. New York: Praeger.

1981. National Party Reform and the Presidential Primaries. Paper presented at annual meeting of the Midwestern Political Science Association, Cincinnati, OH.

1992. The National Democratic Party Can Lead. In James MacGregor Burns, William Crotty, Lois Lovelace Duke, and Lawrence D. Longley, eds., The Democrats Must Lead: The Case for a Progressive Democratic Party. Boulder: Westview Press, Inc.

Maisel, L. Sandy. 1987. Parties and Elections in America: The Electoral Process. New York: Random House.

Martin, John F. 1979. Civil Rights and the Crisis of Liberalism: The Democratic Party 1945-1976. Boulder: Westview Press.

McCullough, David. 1992. Truman. New York: Simon and Schuster.

McKinney, Frank E. 1951a. Acceptance speech. In DNC Library Clipping File. 31 October. HSTL. . 1951 b. Memo to Truman. In Frank E. McKinney Papers. 1 November. HSTL.

Michelson, Charles. 1944. The Ghost Talks. New York: G.P. Putnam's Sons.

Morin, Andrew. 1991. Phone interview. 9 July.

Murphy, Charles S. 1950. Memo to Truman. In Charles S. Murphy Papers. 11 July. HSTL.

Neustadt, Richard. 1991. Interview in Wellfleet. MA. 24 July.

New York Times. 14 October 1951. In DNC Library Clipping File. HSTL.

Panebianco, Angelo. 1988. Political Parties: Organization and Power. Cambridge: Cambridge University Press.

Parmet, Herbert S. 1976. The Democrats: The Years After FDR. New York: Macmillan. 
Polsby. Nelson W. and Aaron Wildavsky. 1976. Presidential Elections: Strategies of American Electoral Politics. New York: Charles S. Scribner's Sons.

Pomper, Gerald M. 1971. Toward a More Responsible Two-Party System? What. Again? Journal of Politics 33: 929-940.

Price. David E. 1984. Bringing Back the Parties. Washington, DC: CQ Press.

Rauh, Joseph. 1991. Interview in Washington, DC. 10 July.

Ranney. Austin. 1951. Toward a More Responsible Two-Party System: A Commentary. American Political Science Review 45: 488-499.

1954. The Doctrine of Responsible Party Government. Urbana: University of Illinois Press.

1975. Curing the Mischiefs of Faction. Berkeley: University of California Press.

Redding. John M. 1948. Memo to J. Howard McGrath. 13 November. In John M. Redding Papers. HSTL.

Roberts, George C. 1987. Paul M. Butler: Hoosier Politician and National Political Leader. Lanham. MD: University Press of America.

Sabato, Larry J. 1988. The Party's Just Begun. Glenview, IL: Scott, Foresman and Company.

Sorauf, Frank J. and Paul A. Beck. 1988. Party Politics in America. Glenview, IL: Scott, Foresman and Company.

Sullivan. Denis G., Jeffrey L. Pressman, Benjamin I. Page, and John L. Lyons. 1974. The Politics of Representation: The Democratic Convention of 1972. New York: St. Martin's Press.

Travis. Alice. 1991. Interview in Washington, DC. 8 July.

Turner, Julius. 1951. Responsible Parties: A Dissent from the Floor. American Political Science Review 45: 143-152.

U.S. News and World Report. 1992. 21 December: 38.

Wekkin, Gary D. 1984. National-State Party Relations: The Democrats' New Federal Structure. Political Science Quarterly 99: 45-72.

Witson, James Q. 1962. The Amateur Democrat. Chicago: University of Chicago Press. 